OPEN ACCESS

Edited by:

Joseph Sorg,

Texas A\&M University, United States

Reviewed by:

Xingmin Sun

University of South Florida,

United States

Larry Kociolek,

Feinberg School of Medicine,

Northwestern University, United States

${ }^{*}$ Correspondence:

Beatrix Förster

b.schafer@umcutrecht.n

Specialty section:

This article was submitted to

Antimicrobials, Resistance and

Chemotherapy,

a section of the journal

Frontiers in Microbiology

Received: 03 April 2018

Accepted: 06 June 2018

Published: 25 June 2018

Citation:

Förster B, Chung PK, Crobach MJT and Kuijper EJ (2018) Application of Antibody-Mediated Therapy for Treatment and Prevention of Clostridium difficile Infection.

Front. Microbiol. 9:1382.

doi: 10.3389/fmicb.2018.01382

\section{Application of Antibody-Mediated Therapy for Treatment and Prevention of Clostridium difficile Infection}

\author{
Beatrix Förster ${ }^{1,2 *}$, Pui Khi Chung ${ }^{3}$, Monique J. T. Crobach ${ }^{3}$ and Ed J. Kuijper ${ }^{3}$ \\ ${ }^{1}$ Department of Medical Microbiology, University Medical Center Utrecht, Utrecht, Netherlands, ${ }^{2}$ Bijvoet Center for \\ Biomolecular Research, Utrecht University, Utrecht, Netherlands, ${ }^{3}$ Department of Medical Microbiology, Centre for Infectious \\ Diseases, Leiden University Medical Center, Leiden, Netherlands
}

Clostridium difficile causes antibiotic- and healthcare-associated diarrhea, which is characterized by a high mortality rate (5-15\%) and high recurrence rate of $20 \%$ or more. Therapeutic alternatives to antibiotics are urgently needed to improve the overall cure rate. Among these, therapeutic antibodies have shown promising results in clinical studies. Herein, the authors review current monoclonal and polyclonal anti- C. difficile antibodies that have entered the clinical development stage, either for systemic administration or by the oral route. The antibodies can be applied as monotherapy or in combination with standard-of-care to treat an infection with $C$. difficile or to protect from a recurrence. Bezlotoxumab is the first antibody for secondary prevention of recurrence of $C$. difficile infection approved by the regulatory agencies in US and Europe. The human monoclonal antibody is administered systemically to patients receiving oral standard-of-care antibiotics. Other antibodies are currently in the clinical pipeline, and some are intended for oral use. They show a good safety profile, high efficacy and low production costs, and can be considered promising therapies of the future. The most promising orally administered drug candidate is a bovine antibody from hyperimmune colostral milk, which is in an advanced clinical development stage. Which antibody will enter the market is dependent on its bioavailability at the site of infection as well as its activity against $C$. difficile toxins, protection against colonization and possible action on spore formation. The antibody must demonstrate a clear benefit in comparison with other available treatment options to be considered for use by clinicians.

Keywords: Clostridium difficile, antibody, therapy, systemic, oral

\section{INTRODUCTION}

Clostridium difficile (CD) is an anaerobic spore-forming bacterium that can be present in the gut of asymptomatic CD carriers (Crobach et al., 2018). However, it is also the most important cause of infectious antibiotic- and healthcare-associated diarrhea (Rupnik et al., 2009; Magill et al., 2014). In patients developing symptomatic C. difficile infection (CDI), symptoms range from mild diarrhea to fulminant life-threatening colitis (Smits et al., 2016). 
The conventional treatment of CDI consists of vancomycin or metronidazole, which are non-selective and lead to further disruption of normal gut microbiota, consequently placing patients at risk for relapse or recurrence. Approximately 25\% of CDI patients experience recurrent disease, which is often difficult to treat (Cornely et al., 2012). Alternatively, fidaxomicin is considered to be a specific anti- $C$. difficile antibiotic, but its application is restricted due to high costs. Recently, antibodymediated therapies for treatment or prevention of CDI have gained attention as alternatives to antibiotic treatment. Here, we discuss the rationale behind antibody-mediated therapy and describe the diverse antibody-mediated therapies (excluding active immunization by vaccines) that are currently studied in the clinic for treatment or prevention (of recurrences) of CDI in humans.

\section{ROLE OF HUMORAL ACTIVITY AGAINST C. DIFFICILE}

Several studies have demonstrated that the adaptive immune response plays an important role in CDI susceptibility, disease course and risk of recurrence. CDI symptoms are caused by the actions of two large enterotoxins, toxin $\mathrm{A}(\mathrm{Tcd} A)$ and $\mathrm{B}$ $(\mathrm{TcdB})$. After the secreted toxins have bound and entered the colonic epithelium, TcdA and TcdB can induce an inflammatory response characterized by chemokine and cytokine production, neutrophil influx, disruption of tight junctions, fluid secretion and cell death (Péchiné and Collignon, 2016; Smits et al., 2016). Some strains, including the more virulent ribotypes 027 and 078, also produce a third toxin, termed binary toxin or CD transferase (CDT). CDT is suggested to cause microtubule-based protrusions on epithelial cells, thereby increasing the adherence of CD to target cells (Smits et al., 2016; Aktories et al., 2018). However, its definite role in pathogenesis remains unclear. CD surface proteins, which mainly act as adhesins, include S-layer proteins, flagellar proteins $\mathrm{FliC}$ and FliD and cell wall proteins (Cwps) such as Cwp84. These surface proteins also contribute to the initiation of the inflammatory response via cytokine production and interaction with toll-like receptors (Péchiné and Collignon, 2016). Inflammation induced by the innate immune response promotes an adaptive immune response with memory.

Both antibodies to $\mathrm{CD}$ toxins and surface proteins have been described, and the adequacy of the humoral immune response can influence susceptibility to $\mathrm{CD}$ colonization and/or progression to CDI. In $55 \mathrm{CDI}$ patients, significantly higher serum IgM anti-SLP (S-layer proteins) antibody levels were found at the initial episode in non-CDI recurring patients compared to patients who went on to develop recurrent CDI (rCDI) (Drudy et al., 2004). Furthermore, serum antibody levels for surface proteins, including FliD and FliC, were significantly higher in control patients than in CDI patients (Péchiné et al., 2005). Therefore, antibodies against CD surface proteins are thought to have a protective role against (re)colonization.

Anti-TcdA and anti-TcdB antibodies can protect colonized patients from progression to CDI or recurrent disease. Anti-toxin antibodies are present in the general population, and antitoxin seropositivity prevalence in the general population of 24 or $66 \%$ have been previously reported (Viscidi et al., 1983; Bacon and Fekety, 1994). Anti-TcdA antibody levels have also been studied in hospitalized patients receiving antibiotic treatment. After intestinal colonization with $C$. difficile, greater increases in serum levels of anti-TcdA IgG were reported in those patients who remained asymptomatic, compared to those who progressed to CDI. Serum anti-TcdA IgG increased rapidly after colonization, indicating the presence of a systemic anamnestic response to TcdA after day three (Kyne et al., 2000). Furthermore, the development of higher serum anti-TcdB and anti-TcdA IgG levels and fecal anti-TcdA IgA levels during the course of CDI were all reported to be associated with a lower risk of rCDI (Aronsson et al., 1985; Warny et al., 1994). In another study, higher antiTcdA IgM and IgG levels at day 12 were associated with a lower risk of recurrence (Kyne et al., 2001). Anti-toxin antibodies may be directly protective against disease by neutralizing secreted toxin. The association of anti-toxin antibodies with decreased recurrence risk may be explained by their ability to remove the toxins and stabilize the gut epithelium and microbiota (Dieterle and Young, 2017).

\section{ANTIBODIES FOR SYSTEMIC ADMINISTRATION TO PREVENT (RELAPSING) CDI}

\section{Actoxumab and Bezlotoxumab}

In 2017, bezlotoxumab (Zinplava ${ }^{(C)}$ ) was approved by the Food and Drug Administration (FDA), and 1 year later by the European Medicines Agency (EMA), as the first monoclonal antibody for prevention of $\mathrm{rCDI}$ in patients $\geq 18$ years old.

Actoxumab and bezlotoxumab were developed in parallel as fully human monoclonal IgG (HuMAbs) directed against $\mathrm{Tcd} A$ and $\mathrm{TcdB}$ respectively. Inactivated $\mathrm{Tcd} A$ and $\mathrm{TcdB}$ (both from Techlab), and additionally recombinant TcdB, were used as antigens to immunize mice transgenic for human immunoglobulin genes (HuMAb mice, Medarex Inc., Bloomsbury, New Jersey) (Babcock et al., 2006). Various hybridomas were obtained and screened in vitro and in vivo. The lead candidate against TcdA (CDA1) recognized the C-terminal region of TcdA and could prevent binding to a cognate receptor on the surface of target cells. The lead candidate against TcdB (MDX-1388) was proposed to bind to the N-terminal domain (putative cell-binding region) of TcdB (Table 1).

A combination treatment with CDA1 and MDX-1388 in a hamster model for primary disease and relapse showed the best outcome. After safety and pharmacokinetics of CDA1 were assessed in healthy volunteers in a phase I clinical trial (Taylor et al., 2008), efficacy of combination treatment with CDA1 and MDX-1388 was examined in a randomized doubleblind, placebo-controlled phase II clinical trial (Lowy et al., 2010). The addition of both antibodies to either metronidazoleor vancomycin-treated patients with CDI significantly reduced recurrence rates. The recurrence rate of patients in the treatment group was $7 \%$, compared to $25 \%$ in the placebo group (Table 2). No significant differences were found in disease severity, number 
TABLE 1 | Clinically tested antibody-mediated therapeutic agents for CDI.

\begin{tabular}{|c|c|c|c|c|c|}
\hline Agent & Manufacturer & Type of antibody & Mode of action & State of development & Indication \\
\hline \multicolumn{6}{|c|}{ SYSTEMIC APPLICATION ROUTE } \\
\hline Actoxumab & $\begin{array}{l}\text { Merck Sharp } \\
\text { \& Dohme Ltd } \\
\text { (Europe), Inc. }\end{array}$ & $\begin{array}{l}\text { Antitoxin A (CDA1, } \\
\text { MK-3415) human } \\
\text { monoclonal lgG antibody }\end{array}$ & $\begin{array}{l}\text { Prevents binding to a } \\
\text { cognate receptor }\end{array}$ & $\begin{array}{l}\text { Terminated after phase III } \\
\text { trial }\end{array}$ & None \\
\hline Bezlotoxumab & $\begin{array}{l}\text { Merck Sharp } \\
\text { \& Dohme Ltd } \\
\text { (Europe), Inc. }\end{array}$ & $\begin{array}{l}\text { Antitoxin B (CDB1, } \\
\text { MDX-1388, MK-6072) } \\
\text { human monoclonal lgG } \\
\text { antibody }\end{array}$ & $\begin{array}{l}\text { Prevents binding to a } \\
\text { cognate receptor }\end{array}$ & FDA and EMA approved & rCDI \\
\hline IVIG & Various & Human $\lg G$ & $\begin{array}{l}\text { Neutralization of } \\
\text { TcdA/TcdB }\end{array}$ & $\begin{array}{l}\text { Market (for other } \\
\text { indications) }\end{array}$ & $\begin{array}{l}\mathrm{rCDI} / \mathrm{CDI} / \text { severe } \\
\mathrm{CDI}\end{array}$ \\
\hline \multicolumn{6}{|c|}{ ORAL APPLICATION ROUTE } \\
\hline IgAbulin & $\begin{array}{l}\text { ImmunoAG } \\
\text { Vienna/Baxter }\end{array}$ & Human IgA & $\begin{array}{l}\text { Neutralization of } \\
\text { TcdA/TcdB }\end{array}$ & $\begin{array}{l}\text { Market (for other } \\
\text { indications) }\end{array}$ & CDI \\
\hline MucoMilk & MucoVax BV & $\begin{array}{l}\text { Polyclonal } \\
\text { antibody-enriched milk } \\
\text { immune whey protein } \\
\text { concentrate }\end{array}$ & $\begin{array}{l}\text { Neutralization of } \\
\text { TcdA/TcdB, Binding of } \\
\text { vegetative bacterial cells }\end{array}$ & Clinical development & rCDI \\
\hline Cediff & $\begin{array}{l}\text { Novatreat } \\
\text { Ltd. }\end{array}$ & $\begin{array}{l}\text { Polyclonal } \\
\text { antibody-enriched } \\
\text { colostral immune whey } \\
\text { protein concentrate }\end{array}$ & $\begin{array}{l}\text { Binding of toxigenic } \\
\text { vegetative bacterial cells }\end{array}$ & $\begin{array}{l}\text { Interrupted in clinical } \\
\text { phase II }\end{array}$ & rCDI \\
\hline IMM-529 & Immuron Ltd. & $\begin{array}{l}\text { Immune colostrum } \\
\text { concentrate }\end{array}$ & $\begin{array}{l}\text { Neutralization of TcdB, } \\
\text { Binding of vegetative } \\
\text { bacterial cells and } \\
\text { endospores }\end{array}$ & Clinical phase I/II & $\mathrm{CDI} / \mathrm{rCDI}$ \\
\hline
\end{tabular}

IVIG, intravenous immunoglobulin; TcdA, C. difficile toxin A; TcdB, C. difficile toxin B; CDI, C. difficile disease; rCDI, recurrent CDI.

of days to resolution, or proportion of treatment failure. Adverse events were reported to be similar in both groups.

The worldwide development and commercialization rights for both antibodies were purchased by Merck for US\$ 60 million, (Markham, 2016) and two double-blind, placebo-controlled phase III trials, MODIFY I and II, were conducted to assess efficacy and safety of both antibodies (subsequently named actoxumab and bezlotoxumab) (Wilcox et al., 2017). MODIFY I had an adaptive design, allowing enrolment cessation in any group after interim analysis. Patients were randomly assigned in a 1:1:1:1 ratio to either receive a single dose of bezlotoxumab, actoxumab, bezlotoxumab plus actoxumab or placebo in addition to standard antibiotic treatment for CDI. During the interim analysis of MODIFY I, higher mortality and more serious adverse events were found in the actoxumab group, causing enrolment in this group to be terminated. Subsequently, actoxumab was not evaluated in MODIFY II. While in both trials initial cure rates did not differ between antibody-treated groups and placebo groups, significantly lower recurrence of CDI was found in the bezlotoxumab groups during 12 weeks post-treatment, as recurrent infections were seen in 17 and $16 \%$ in these groups in MODIFY I and II respectively, in comparison to 28 and $26 \%$ in the placebo groups (Table 2). Subgroup analysis of initially cured participants similarly showed significant differences in the recurrence rate, while sensitivity analysis taking into account missing data and early discontinuations were consistent with these findings. The addition of actoxumab to bezlotoxumab did not improve efficacy in MODIFY I. The overall safety profile of bezlotoxumab was favorable, though the assessment reports of FDA and EMA noted a numerical increment of heart failure and all-cause mortality among bezlotoxumab treated subjects with baseline congestive heart failure, compared to placebo-treated patients.

The benefit of bezlotoxumab and actoxumab-bezlotoxumab was confirmed in subpopulations at high risk for rCDI or CDI complications. Post-hoc analyses of the two phase 3 trials (MODIFY 1 and MODIFY II) showed greater benefit of bezlotoxumab than placebo in patients with at least three risk factors. No difference in CDI recurrence was observed for patients with no predefined risk factors (Gerding et al., 2018).

Bezlotoxumab is available for the retail price of $\$ 4,560$ per vial (Lee et al., 2017). In a model-based analysis of the MODIFY trial subjects by the manufacturer, bezlotoxumab was reported to be cost-effective compared to placebo (Prabhu et al., 2018), although no reports of comparison to other approaches such as fecal transplant or fidaxomicin treatment have been published.

\section{Intravenous Immunoglobulin}

In contrast to monoclonal antibody therapies, a cocktail of synergistic polyclonal antibodies has the ability to bind multiple 
TABLE 2 | Studies evaluating antibody-mediated therapeutics in humans.

\begin{tabular}{llll}
\hline Agent & Study (author, year) & Study design & Efficacy
\end{tabular}

\section{SYSTEMIC APPLICATION ROUTE}

Actoxumab (CDA1) Wilcox et al., 2017

(1)

Bezlotoxumab (MDX1388) Wilcox et al., 2017

Actoxumab- $\quad$ Lowy et al., 2010
bezlotoxumab

IVIG

\section{ORAL APPLICATION ROUTE}

\section{IgAbulin}

MucoMilk

Numan et al., 2007

Cediff

Mattila et al., 2008
Wilcox et al., 2017

Leung et al., 1991

Wilcox, 2004; McPherson et al., 2006; Negm et al., 2017

Juang et al., 2007;

Shahani and Koirala, 2015

\section{Clinical Phase III study}

MODIFY I:

Addition of actoxumab, bezlotoxumab, a-b or placebo to SoC treatment in adult (r)CDI patients Clinical Phase III study

Addition of bezlotoxumab ( $n=781$ ) vs. placebo

$(n=773)$ to SoC treatment in adult (r)CDI

patients

MODIFY I

MODIFY II

Clinical Phase I/ study

Addition of CDA1+ and MDX1388 in single

infusion ( $n=101)$ vs. placebo $(n=99)$ to SoC

treatment for $\mathrm{CDI}$

Clinical phase III study

Addition of actoxumab-bezlotoxumab $(n=773)$

vs. placebo $(n=773)$ to SoC treatment in adult (r)CDI patients

MODIFY I

MODIFY ॥

Case series

5 pediatric patients with hypoglobulinaemia and rCDI, $400 \mathrm{mg} / \mathrm{kg}$ IVIG

Retrospective studies

36 adult patients with (r)CDI, 150-500 mg/kg

IVIG

Retrospective studies

39 adult patients with severe CDI, 82 control patients, $400 \mathrm{mg} / \mathrm{kg}$ IVIG

Tjellström et al., 1993

\section{Case study}

1 pediatric patient with severe CDI

Prospective cohort study

15 adult patients, 1 pediatric patient with

completed antibiotic therapy, under which 9 patients with rCDI

Prospective cohort study

101 adult patients, with completed antibiotic

therapy, 61 patients with CDI 40 patients with

rCDI (40\%)

\section{Prospective study}

38 adult patients with $\mathrm{rCDI}$

20 were treated with Cediff, 18 were treated with

metronidazole
Higher mortality and more AE in actoxumab group; evaluation terminated

No difference initial cure rate ( $77 \%$ vs. $83 \%)$ Significant lower rCDI (17\% vs. $28 \%$ )

No difference initial cure rate ( $83 \%$ vs. $78 \%$ ) Significant lower rCDI (16\% vs. $26 \%$ )

Significant lower laboratory-documented rCDI: $7 \%$ comparator vs. $25 \%$ placebo

No difference initial cure rate ( $75 \%$ vs. $83 \%)$ Significant lower rCDI(16\% vs. $28 \%)$

No difference initial cure rate ( $72 \%$ vs. $78 \%$ )

Significant lower rCDI (15\% vs. 26\%)

All patients had full resolution of symptoms

24 patients showed therapeutic response, 12 did not respond

No significant differences regarding outcome and severity of symptoms

Full resolution of symptoms

No relapse within a median follow-up period of 333 days

Prevention of relapse by $50 \%$ during a follow up period of 60 days

Cediff was as effective as metronidazole in the prevention of $\mathrm{CDI}$ recurrences during a 70 day follow up (sustained recovery $56 \%$ vs. $55 \%$ )

a-b, actoxumab-bezlotoxumab; AE, adverse event; SOC, standard-of-care; CDI, C. difficile disease; CDA1, human monoclonal anti-toxin A; CDB1, human monoclonal anti-toxin B; rCDI, recurrent CDI; SoC, standard-of-care antibiotic treatment for CDI; TCdA, C. difficile toxin A; TCdB, C. difficile toxin B; vs., versus; IVIG, intravenous immunoglobulin.

targets and mediate a variety of effector functions (Wang et al., 2013).

Intravenous immunoglobulin (IVIG) is in use for numerous clinically approved pathological conditions (Hässig, 1967; Stiehm et al., 2008), and in more than 100 different indications as an off-label drug (João et al., 2018). The rationale to apply IVIG to patients with CDI is based on the prevalence of serum antibodies against TcdA and TcdB in healthy blood donors (Viscidi et al.,
1983; Bacon and Fekety, 1994), and a low antitoxin serum level in patients that are predisposed for recurrent, prolonged or severe CDI (Salcedo et al., 1997; Kyne et al., 2000; Table 1). After a successful study in children (Leung et al., 1991) IVIG has been used in several small, mostly retrospective and nonrandomized studies with elderly patients suffering from recurrent (Beales, 2002; Wilcox, 2004) or severe CDI (Salcedo et al., 1997; McPherson et al., 2006; Juang et al., 2007; Shah et al., 2014; 
Shahani and Koirala, 2015; Table 2). So far, there is a lack of robust evidence of a beneficial therapeutic effect of IVIG due to the absence of a sufficiently powered randomized controlled trial (Negm et al., 2017). In 2005, a randomized placebo- controlled interventional study planned for 40 patients with severe relapsing or refractory CDI (ClinicalTrials.gov NCT00177970) was started and prematurely terminated. The sponsor states that they were unable to receive IVIG free of cost from a pharmaceutical company to continue.

In addition to the lack of consensus regarding optimal dose and timing of IVIG administration and patient selection, the quality of IVIG is a pivotal factor. Plasma or blood of 1,000100,000 healthy donors is used for IVIG manufacturing and the compositions of plasma donor pools are not standardized. Recently, three commercially available IVIG preparations were screened for their reactivity to a panel of seven CD antigens. They showed significant differences in antigen binding and toxin neutralization, which are considered as the predominant mode of action of IVIG against CDI (Negm et al., 2017). Selected sourcing of donors with naturally occurring anti-toxin antibodies for the manufacturing of IVIG with standardized elevated specific antibody levels is feasible (Wasserman et al., 2016). It is questionable if the market size of severe and rCDI and predominance of low-cost medication can offer an incentive to invest into a specialized IVIG.

As a blood-derived product, IgG pool carries a potential (low) risk for blood-borne disease transmission (Chapel, 1999) and contains batch-to-batch variability. Additionally, only a small fraction of antibodies bind the target of interest. The biodistribution of IVIG outside the bloodstream is poorly understood (Brandtzaeg and Baklien, 1976; Wasserman et al., 2012; Nikpoor et al., 2015), and it is unclear if the concentration of antibody that reaches the site of infection could be sufficient to exert the desired effect.

Furthermore, IVIG may not be cost-effective and would not relieve the financial burden on health care. While each CDI episode costs $\$ 3,500-5,042$ (Dubberke et al., 2008), each IVIG administration is calculated at $\$ 4551.25$ (Blackhouse et al., 2010).

\section{ANTIBODIES FOR ORAL APPLICATION AGAINST CDI}

Oral delivery of antibodies to target pathogens restricted to the gastrointestinal tract provides a highly attractive treatment strategy. A needle-free application directly on the affected site may result in a higher efficacy with reduced side-effects at a lower dose (Jones and Martino, 2016). Human and bovine antibodies have been used in the past to treat CDI.

\section{Human Antibodies}

A human IgA and IgG pool (Tjellström et al., 1993; Saturno, 2006) derived from healthy blood donors was successfully used to orally treat children with severe CDI resistant to standard treatment (Table 2). Consistent with findings for infants orally treated with human IgG (Blum et al., 1981), IgA remained restricted to the gastrointestinal tract and did not enter the blood stream (Casswall et al., 1996).

\section{Bovine Antibodies}

Hyperimmune bovine colostrum (HBC) or milk is an easily scalable and cost-effective source (USD\$1/gram antibody; Hutton et al., 2017) for orally applicable antibodies with a strong safety profile. It is produced by vaccination of cows during gestation, and is rich in targeted $\operatorname{IgG}$ or secretory $\operatorname{IgA}(\operatorname{sg} \mathrm{A})$.

HBC derived from cows that were immunized with recombinant mutants of $\mathrm{TcdA}$ and $\mathrm{TcdB}$ showed a therapeutic efficacy in gnotobiotic piglets with diarrhea due to CDI (Sponseller et al., 2015).

A single-site, open, crossover, clinical phase I study on six healthy volunteers was performed to analyse the survival of bovine IgG in the human gastrointestinal tract after application of a single oral dose. Antibody-enriched colostral immune whey protein concentrate (BIC) was derived from cows immunized with either a toxoid derived from culture medium of toxigenic CD containing both TcdA and B, or a toxoid of purified TcdA (Kelly et al., 1997). Antibody within enteric coated capsules could be recovered to about $30 \%$ of the initial dose in stool while retaining its specific toxin-neutralizing activity. Based on in vitro and preclinical findings, it was assumed that the bovine IgG could neutralize CD toxins within the colonic lumen (Kelly et al., 1997). This study also claimed bovine IgG concentrate against CD to be safe for oral use in humans. The following single site, open, phase I study was performed on six volunteers with an end ileostomy to examine safety and bioavailability of a single oral dose. This study showed the recovery of about $50 \%$ of the orally applied antibody and a retained activity. It also revealed the difficulty of properly formulating the oral antibody therapy for patients with abnormal mouth to ileum transit times (Warny et al., 1999).

Immune whey protein concentrate derived from mature milk of cows vaccinated with formaldehyde-inactivated whole CD cells (VPI10463) and toxoid prepared from the CD culture filtrate contained a high concentration of specific sIgA antibodies (Schmautz et al., 2018; Table 1). This product, named MucoMilk, was intended to serve as "clinical nutrition" (not medication) for patients with CDI and considered to be safe (Young et al., 2007). The prevention of relapses of CDI was evaluated in a prospective uncontrolled cohort study enrolling 16 patients with CDI. The whey concentrate was applied subsequently to standard antibiotic treatment. During a follow-up period of median 333 days, none of the patients had experienced a relapse (van Dissel et al., 2005). A following non-blinded, clinical cohort study applying the same treatment scheme on 101 patients showed a reduction of recurrence by about 50\% (van Dissel et al., 2005; Numan et al., 2007; Bauer et al., 2008; Bauer and van Dissel, 2009; Table 2).

Next, a controlled, double-blind, randomized, parallel-group, multicenter trial with concentrated colostral immune whey from cows vaccinated with formaldehyde-inactivated whole CD cells (T-37067, T-36842), named Cediff, was performed (Table 1). Cediff was compared with metronidazole against rCDI in patients that already encountered at least one episode. Although only a small number of patients were included, the recurrence rate of both treatment groups was similar (Mattila et al., 2008; Table 2). Further development was stopped.

Recently, a phase $1 / 2$, randomized, double blind, placebocontrolled clinical study started enrolling patients with primary and $\mathrm{rCDI}$, to evaluate safety and tolerability of hyper-immune 
bovine colostrum powder (IMM-529) together with standardof-care (ClinicalTrials.gov NCT03065374). IMM-529 is derived from cows vaccinated with $\mathrm{TcdB}$, vegetative cells and endospores of CD (Hutton et al., 2017; Table 1). In contrast to previous approaches (Korhonen et al., 2000) the immune colostrum powder is produced as pharmaceutical.

\section{PERSPECTIVE}

Further antibodies against CDI are in preclinical development, such as avian antibodies against TcdA and B (Kink and Williams, 1998) or spores (Pizarro-Guajardo et al., 2017) and fully human polyclonal IgG obtained by immunization of transgenic cattle with a trivalent and quadravalent toxin vaccine (Tian et al., 2017).

Smaller antibody formats such as a tetravalent bispecific heavy-chain-only single domain ( $\mathrm{VHH}$ ) antibody against TcdA and $\mathrm{B}$ features neutralization in a subnanomolar range and efficacy in animal models of CDI and is deliverable by gene therapy (Yang et al., 2014, 2016). Engineered lactobacilli that produce variable domains of heavy chain only antibodies against $\mathrm{CD}$ toxins show partial protection in a hamster model (Andersen et al., 2016).

Fully functional antibodies that consist of heavy chains only are named nanobodies. Nanobodies against binary toxin (Unger et al., 2015) and surface proteins of CD (Kandalaft et al., 2015) as well as variable domains derived from cartilaginous shark IgNAR (Krah et al., 2016) have shown effects in vitro. A camelid single domain antibody against TcdA could be easily optimized

\section{REFERENCES}

Aktories, K., Papatheodorou, P., and Schwan, C. (2018). Binary Clostridium difficile toxin (CDT) - a virulence factor disturbing the cytoskeleton. Anaerobe. doi: 10.1016/j.anaerobe.2018.03.001. [Epub ahead of print].

Andersen, K. K., Strokappe, N. M., Hultberg, A., Truusalu, K., Smidt, I., Mikelsaar, R. H., et al. (2016). Neutralization of Clostridium difficile toxin B mediated by engineered lactobacilli that produce single-domain antibodies. Infect. Immun. 84, 395-406. doi: 10.1128/IAI.00870-15

Aronsson, B., Granström, M., Möllby, R., and Nord, C. E. (1985). Serum antibody response to Clostridium difficile toxins in patients with Clostridium difficile diarrhoea. Infection 13, 97-101. doi: 10.1007/BF01642866

Babcock, G. J., Broering, T. J., Hernandez, H. J., Mandell, R. B., Donahue, K., Boatright, N., et al. (2006). Human monoclonal antibodies directed against toxins A and B prevent Clostridium difficile-induced mortality in hamsters. Infect. Immun. 74, 6339-6347. doi: 10.1128/IAI.00982-06

Bacon, A. E. III., and Fekety, R. (1994). Immunoglobulin G directed against toxins A and B of Clostridium difficile in the general population and patients with antibiotic-associated diarrhea. Diagn. Microbiol. Infect. Dis. 18, 205-209. doi: 10.1016/0732-8893(94)90021-3

Bauer, M. P., Numan-Ruberg, S. C., Bredewold, O. W., Kuijper, E. J., MooiKokenberg, E. A., Debast, S. B., et al. (2008). Recurrence of Clostridium difficileassociated diarrhoea prevented by the administration of a whey concentrate from specifically immunised cows; prospective study. Ned. Tijdschr. Geneeskd. 152, 1919-1926.

Bauer, M. P., and van Dissel, J. T. (2009). Alternative strategies for Clostridium difficile infection. Int. J. Antimicrob. Agents 33(Suppl. 1), S51-S56. doi: 10.1016/S0924-8579(09)70018-4

Beales, I. L. (2002). Intravenous immunoglobulin for recurrent Clostridium difficile diarrhoea. Gut 51:456. doi: 10.1136/gut.51.3.456 by an affinity maturation platform and could serve as an alternative therapeutic modality in the future (Sulea et al., 2018). A novel humanized monoclonal antibody recognizes a single, highly conserved epitope on the TcdB glucosyltransferase domain and neutralizes $\mathrm{TcdB}$ from various $\mathrm{CD}$ strains (Kroh et al., 2018).

\section{CONCLUSION}

Taken together, antibodies such as bezlotoxumab have proven to be capable of protecting from rCDI, while mostly being directed against toxins. A better understanding of virulence factors of CD could help to broaden the repertoire of therapeutic targets and may result in antibodies also applicable for severe and refractory CDI or CDI caused by "hypervirulent" strains. Due to their property of maintaining the integrity of the gut microflora and providing no selective pressure for escape mutants (Steele et al., 2013), polyclonal antibodies could act synergistically with antibiotics and FMT and could easily be integrated in treatment regimens, provided that their costs are competitive with current therapies. Oral antibodies have the clear advantage that they could be applied not only at the clinic but also at the patient's home.

\section{AUTHOR CONTRIBUTIONS}

$\mathrm{BF}, \mathrm{PC}, \mathrm{MC}$, and EK have written the manuscript and compiled the tables.
Blackhouse, G., Gaebel, K., Xie, F., Campbell, K., Assasi, N., Tarride, J. E., et al. (2010). Cost-utility of Intravenous Immunoglobulin (IVIG) compared with corticosteroids for the treatment of Chronic Inflammatory Demyelinating Polyneuropathy (CIDP) in Canada. Cost Eff. Resour. Alloc. 8:14. doi: $10.1186 / 1478-7547-8-14$

Blum, P. M., Phelps, D. L., Ank, B. J., Krantman, H. J., and Stiehm, E. R. (1981). Survival of oral human immune serum globulin in the gastrointestinal tract of low birth weight infants. Pediatr. Res. 15, 1256-1260. doi: 10.1203/00006450-198109000-00006

Brandtzaeg, P., and Baklien, K. (1976). Immunohistochemical studies of the formation and epithelial transport of immunoglobulins in normal and diseased human intestinal mucosa. Scand. J. Gastroenterol. Suppl. 36, 1-45.

Casswall, T. H., Hammarstrom, L., Veress, B., Nord, C. E., Bogstedt, A., Brockstedt, U., et al. (1996). Oral IgA-IgG treatment of chronic nonspecific diarrhoea in infants and children. Acta Paediatr. 85, 1126-1128. doi: 10.1111/j.1651-2227.1996.tb14231.x

Chapel, H. M. (1999). Safety and availability of immunoglobulin replacement therapy in relation to potentially transmissable agents. IUIS Committee on Primary Immunodeficiency Disease. International Union of Immunological Societies. Clin. Exp. Immunol. 118(Suppl. 1), 29-34. doi: 10.1046/j.1365-2249.1999.00000.x

Cornely, O. A., Miller, M. A., Louie, T. J., Crook, D. W., and Gorbach, S. L. (2012). Treatment of first recurrence of Clostridium difficile infection: fidaxomicin versus vancomycin. Clin. Infect. Dis. 55(Suppl. 2), S154-S161. doi: $10.1093 /$ cid/cis462

Crobach, M. J. T., Vernon, J. J., Loo, V. G., Kong, L. Y., Pechine, S., Wilcox, M. H., et al. (2018). Understanding Clostridium difficile colonization. Clin. Microbiol. Rev. 31:e00021-17. doi: 10.1128/CMR.00021-17

Dieterle, M. G., and Young, V. B. (2017). Reducing recurrence of C. difficile Infection. Cell 169, 375. doi: 10.1016/j.cell.2017.03.039 
Drudy, D., Calabi, E., Kyne, L., Sougioultzis, S., Kelly, E., Fairweather, N., et al. (2004). Human antibody response to surface layer proteins in Clostridium difficile infection. FEMS Immunol. Med. Microbiol. 41, 237-242. doi: 10.1016/j.femsim.2004.03.007

Dubberke, E. R., Reske, K. A., Olsen, M. A., McDonald, L. C., and Fraser, V. J. (2008). Short- and long-term attributable costs of Clostridium difficileassociated disease in nonsurgical inpatients. Clin. Infect. Dis. 46, 497-504. doi: $10.1086 / 526530$

Gerding, D. N., Kelly, C. P., Rahav, G., Lee, C., Dubberke, E. R., Kumar, P. N., et al. (2018). Bezlotoxumab for prevention of recurrent $C$. difficile infection in patients at increased risk for recurrence. Clin Infect Dis. doi: 10.1093/cid/ciy171. [Epub ahead of print]

Hässig, A. (1967). On the prophylaxis and therapy with human immune globulin preparations. Bibl. Haematol. 27, 239-252.

Hutton, M. L., Cunningham, B. A., Mackin, K. E., Lyon, S. A., James, M. L., Rood, J. I., et al. (2017). Bovine antibodies targeting primary and recurrent Clostridium difficile disease are a potent antibiotic alternative. Sci. Rep. 7:3665. doi: 10.1038/s41598-017-03982-5

João, C., Negi, V. S., Kazatchkine, M. D., Bayry, J., and Kaveri, S. V. (2018). Passive serum therapy to immunomodulation by IVIG: a fascinating journey of Antibodies. J. Immunol. 200, 1957-1963. doi: 10.4049/jimmunol.1701271

Jones, R. G., and Martino, A. (2016). Targeted localized use of therapeutic antibodies: a review of non-systemic, topical and oral applications. Crit. Rev. Biotechnol. 36, 506-520. doi: 10.3109/07388551.2014.992388

Juang, P., Skledar, S. J., Zgheib, N. K., Paterson, D. L., Vergis, E. N., Shannon, W. D., et al. (2007). Clinical outcomes of intravenous immune globulin in severe clostridium difficile-associated diarrhea. Am. J. Infect. Control 35, 131-137. doi: 10.1016/j.ajic.2006.06.007

Kandalaft, H., Hussack, G., Aubry, A., van Faassen, H., Guan, Y., ArbabiGhahroudi, M., et al. (2015). Targeting surface-layer proteins with singledomain antibodies: a potential therapeutic approach against Clostridium difficile-associated disease. Appl. Microbiol. Biotechnol. 99, 8549-8562. doi: 10.1007/s00253-015-6594-1

Kelly, C. P., Chetham, S., Keates, S., Bostwick, E. F., Roush, A. M., Castagliuolo, I., et al. (1997). Survival of anti-Clostridium difficile bovine immunoglobulin concentrate in the human gastrointestinal tract. Antimicrob. Agents Chemother. 41, 236-241.

Kink, J. A., and Williams, J. A. (1998). Antibodies to recombinant Clostridium difficile toxins $\mathrm{A}$ and $\mathrm{B}$ are an effective treatment and prevent relapse of C. difficile-associated disease in a hamster model of infection. Infect. Immun. 66, 2018-2025

Korhonen, H., Marnila, P., and Gill, H. S. (2000). Bovine milk antibodies for health. Br. J. Nutr. 84(Suppl. 1), S135-146. doi: 10.1017/S0007114500002361

Krah, S., Schroter, C., Zielonka, S., Empting, M., Valldorf, B., and Kolmar, H. (2016). Single-domain antibodies for biomedical applications. Immunopharmacol. Immunotoxicol. 38, 21-28. doi: $10.3109 / 08923973.2015 .1102934$

Kroh, H. K., Chandrasekaran, R., Zhang, Z., Rosenthal, K., Woods, R., Jin, X., et al. (2018). A neutralizing antibody that blocks delivery of the enzymatic cargo of Clostridium difficile toxin TcdB into host cells. J. Biol. Chem. 293, 941-952. doi: 10.1074/jbc.M117.813428

Kyne, L., Warny, M., Qamar, A., and Kelly, C. P. (2000). Asymptomatic carriage of Clostridium difficile and serum levels of IgG antibody against toxin A. N. Engl. J. Med. 342, 390-397. doi: 10.1056/NEJM200002103420604

Kyne, L., Warny, M., Qamar, A., and Kelly, C. P. (2001). Association between antibody response to toxin $\mathrm{A}$ and protection against recurrent Clostridium difficile diarrhoea. Lancet 357, 189-193. doi: 10.1016/S0140-6736(00)03592-3

Lee, Y., Lim, W. I., Bloom, C. I., Moore, S., Chung, E., and Marzella, N. (2017). Bezlotoxumab (Zinplava) for clostridium difficile infection: the first monoclonal antibody approved to prevent the recurrence of a bacterial infection. $P$ T 42, 735-738

Leung, D. Y., Kelly, C. P., Boguniewicz, M., Pothoulakis, C., LaMont, J. T., and Flores, A. (1991). Treatment with intravenously administered gamma globulin of chronic relapsing colitis induced by Clostridium difficile toxin. J. Pediatr. 118(4 Pt 1), 633-637. doi: 10.1016/S0022-3476(05)83393-1

Lowy, I., Molrine, D. C., Leav, B. A., Blair, B. M., Baxter, R., Gerding, D. N., et al. (2010). Treatment with monoclonal antibodies against Clostridium difficile toxins. N. Engl. J. Med. 362, 197-205. doi: 10.1056/NEJMoa0907635
Magill, S. S., Edwards, J. R., Bamberg, W., Beldavs, Z. G., Dumyati, G., Kainer, M. A., et al. (2014). Multistate point-prevalence survey of health care-associated infections. N. Engl. J. Med. 370, 1198-1208. doi: 10.1056/NEJMoa1306801

Markham, A. (2016). Bezlotoxumab: first global approval. Drugs 76, 1793-1798. doi: 10.1007/s40265-016-0673-1

Mattila, E., Anttila, V. J., Broas, M., Marttila, H., Poukka, P., Kuusisto, K., et al. (2008). A randomized, double-blind study comparing Clostridium difficile immune whey and metronidazole for recurrent Clostridium difficile-associated diarrhoea: efficacy and safety data of a prematurely interrupted trial. Scand. J. Infect. Dis. 40, 702-708. doi: 10.1080/00365540801964960

McPherson, S., Rees, C. J., Ellis, R., Soo, S., and Panter, S. J. (2006). Intravenous immunoglobulin for the treatment of severe, refractory, and recurrent Clostridium difficile diarrhea. Dis. Colon Rectum 49, 640-645. doi: 10.1007/s10350-006-0511-8

Negm, O. H., MacKenzie, B., Hamed, M. R., Ahmad, O. A. J., Shone, C. C., Humphreys, D. P., et al. (2017). Protective antibodies against Clostridium difficile are present in intravenous immunoglobulin and are retained in humans following its administration. Clin. Exp. Immunol. 188, 437-443. doi: 10.1111/cei.12946

Nikpoor, A. R., Tavakkol-Afshari, J., Gholizadeh, Z., Sadri, K., Babaei, M. H., Chamani, J., et al. (2015). Nanoliposome-mediated targeting of antibodies to tumors: IVIG antibodies as a model. Int. J. Pharm. 495, 162-170. doi: 10.1016/j.ijpharm.2015.08.048

Numan, S. C., Veldkamp, P., Kuijper, E. J., van den Berg, R. J., and van Dissel, J. T. (2007). Clostridium difficile-associated diarrhoea: bovine anti-Clostridium difficile whey protein to help aid the prevention of relapses. Gut 56, 888-889. doi: 10.1136/gut.2006.119016

Péchiné, S., and Collignon, A. (2016). Immune responses induced by Clostridium difficile. Anaerobe 41, 68-78. doi: 10.1016/j.anaerobe.2016.04.014

Péchiné, S., Gleizes, A., Janoir, C., Gorges-Kergot, R., Barc, M. C., Delmée, M., et al. (2005). Immunological properties of surface proteins of Clostridium difficile. J. Med. Microbiol. 54(Pt 2), 193-196. doi: 10.1099/jmm.0.45800-0

Pizarro-Guajardo, M., Diaz-Gonzalez, F., Alvarez-Lobos, M., and Paredes-Sabja, D. (2017). Characterization of chicken IgY specific to Clostridium difficile R20291 spores and the effect of oral administration in mouse models of initiation and recurrent disease. Front. Cell. Infect. Microbiol. 7:365. doi: 10.3389/fcimb.2017.00365

Prabhu, V. S., Dubberke, E. R., Dorr, M. B., Elbasha, E., Cossrow, N., Jiang, Y., et al. (2018). Cost-effectiveness of bezlotoxumab compared with placebo for the prevention of recurrent Clostridium difficile infection. Clin. Infect. Dis. 66, 355-362. doi: 10.1093/cid/cix809

Rupnik, M., Wilcox, M. H., and Gerding, D. N. (2009). Clostridium difficile infection: new developments in epidemiology and pathogenesis. Nat. Rev. Microbiol. 7, 526-536. doi: 10.1038/nrmicro2164

Salcedo, J., Keates, S., Pothoulakis, C., Warny, M., Castagliuolo, I., LaMont, J. T., et al. (1997). Intravenous immunoglobulin therapy for severe Clostridium difficile colitis. Gut 41, 366-370. doi: 10.1136/gut.41.3.366

Saturno (2006). Abstracts of the American Academy of Allergy, Asthma and Immunology (AAAAI) 62nd Annual Meeting, March 3-7, 2006, Miami Beach, Florida, USA. J. Allergy Clin. Immunol. 117(2 Suppl. AAAAI 62ND), S1-S330.

Schmautz, C., Hillreiner, M., Ballweg, I., Pfaffl, M. W., and Kliem, H. (2018). Stimulated enrichment of Clostridium difficile specific IgA in mature cow's milk. PLoS ONE 13:e0195275. doi: 10.1371/journal.pone.0195275

Shah, N., Shaaban, H., Spira, R., Slim, J., and Boghossian, J. (2014). Intravenous immunoglobulin in the treatment of severe clostridium difficile colitis. J. Glob. Infect. Dis. 6, 82-85. doi: 10.4103/0974-777X.132053

Shahani, L., and Koirala, J. (2015). Use of intravenous immunoglobulin in severe Clostridium difficile-associated diarrhea. Hosp. Pract. 43, 154-157. doi: 10.1080/21548331.2015.1071636

Smits, W. K., Lyras, D., Lacy, D. B., Wilcox, M. H., and Kuijper, E. J. (2016). Clostridium difficile infection. Nat Rev Dis Primers 2:16020. doi: $10.1038 / \mathrm{nrdp} .2016 .20$

Sponseller, J. K., Steele, J. A., Schmidt, D. J., Kim, H. B., Beamer, G., Sun, X., et al. (2015). Hyperimmune bovine colostrum as a novel therapy to combat Clostridium difficile infection. J. Infect. Dis. 211, 1334-1341. doi: 10.1093/infdis/jiu605

Steele, J., Sponseller, J., Schmidt, D., Cohen, O., and Tzipori, S. (2013). Hyperimmune bovine colostrum for treatment of GI infections: a review 
and update on Clostridium difficile. Hum. Vaccin. Immunother. 9, 1565-1568. doi: $10.4161 /$ hv. 24078

Stiehm, E. R., Keller, M. A., and Vyas, G. N. (2008). Preparation and use of therapeutic antibodies primarily of human origin. Biologicals 36, 363-374. doi: 10.1016/j.biologicals.2008.07.002

Sulea, T., Hussack, G., Ryan, S., Tanha, J., and Purisima, E. O. (2018). Application of assisted design of antibody and protein therapeutics (ADAPT) improves efficacy of a Clostridium difficile toxin A single-domain antibody. Sci. Rep. 8, 2260. doi: 10.1038/s41598-018-20599-4

Taylor, C. P., Tummala, S., Molrine, D., Davidson, L., Farrell, R. J., Lembo, A., et al. (2008). Open-label, dose escalation phase I study in healthy volunteers to evaluate the safety and pharmacokinetics of a human monoclonal antibody to Clostridium difficile toxin A. Vaccine 26, 3404-3409. doi: 10.1016/j.vaccine.2008.04.042

Tian, J. H., Glenn, G., Flyer, D., Zhou, B., Liu, Y., Sullivan, E., et al. (2017). Clostridium difficile chimeric toxin receptor binding domain vaccine induced protection against different strains in active and passive challenge models. Vaccine 35, 4079-4087. doi: 10.1016/j.vaccine.2017. 06.062

Tjellström, B., Stenhammar, L., Eriksson, S., and Magnusson, K. E. (1993). Oral immunoglobulin A supplement in treatment of Clostridium difficile enteritis. Lancet 341, 701-702. doi: 10.1016/0140-6736(93)90477-X

Unger, M., Eichhoff, A. M., Schumacher, L., Strysio, M., Menzel, S., Schwan, C., et al. (2015). Selection of nanobodies that block the enzymatic and cytotoxic activities of the binary Clostridium difficile toxin CDT. Sci. Rep. 5:7850. doi: $10.1038 /$ srep 07850

van Dissel, J. T., de Groot, N., Hensgens, C. M., Numan, S., Kuijper, E. J., Veldkamp, P., et al. (2005). Bovine antibody-enriched whey to aid in the prevention of a relapse of Clostridium difficile-associated diarrhoea: preclinical and preliminary clinical data. J. Med. Microbiol. 54(Pt 2), 197-205. doi: 10.1099/jmm.0.45773-0

Viscidi, R., Laughon, B. E., Yolken, R., Bo-Linn, P., Moench, T., Ryder, R. W., et al. (1983). Serum antibody response to toxins A and B of Clostridium difficile. J. Infect. Dis. 148, 93-100. doi: 10.1093/infdis/148.1.93

Wang, X. Z., Coljee, V. W., and Maynard, J. A. (2013). Back to the future: recombinant polyclonal antibody therapeutics. Curr. Opin. Chem. Eng. 2, 405-415. doi: 10.1016/j.coche.2013.08.005

Warny, M., Fatimi, A., Bostwick, E. F., Laine, D. C., Lebel, F., LaMont, J. T., et al. (1999). Bovine immunoglobulin concentrate-clostridium difficile retains $\mathrm{C}$ difficile toxin neutralising activity after passage through the human stomach and small intestine. Gut 44, 212-217. doi: 10.1136/gut. 44.2.212
Warny, M., Vaerman, J. P., Avesani, V., and Delmee, M. (1994). Human antibody response to Clostridium difficile toxin A in relation to clinical course of infection. Infect. Immun. 62, 384-389.

Wasserman, R. L., Church, J. A., Stein, M., Moy, J., White, M., Strausbaugh, S., et al. (2012). Safety, efficacy and pharmacokinetics of a new $10 \%$ liquid intravenous immunoglobulin (IVIG) in patients with primary immunodeficiency. J. Clin. Immunol. 32, 663-669. doi: 10.1007/s10875-012-9656-5

Wasserman, R. L., Lumry, W., Harris, J. III., Levy, R., Stein, M., Forbes, L., et al. (2016). Efficacy, safety, and pharmacokinetics of a new $10 \%$ liquid intravenous immunoglobulin containing high titer neutralizing antibody to RSV and other respiratory viruses in subjects with primary immunodeficiency disease. J. Clin. Immunol. 36, 590-599. doi: 10.1007/s10875-016-0308-Z

Wilcox, M. H. (2004). Descriptive study of intravenous immunoglobulin for the treatment of recurrent Clostridium difficile diarrhoea. J. Antimicrob. Chemother. 53, 882-884. doi: 10.1093/jac/dkh176

Wilcox, M. H., Gerding, D. N., Poxton, I. R., Kelly, C., Nathan, R., Birch, T., et al. (2017). Bezlotoxumab for prevention of recurrent Clostridium difficile infection. N. Engl. J. Med. 376, 305-317. doi: 10.1056/NEJMoa1602615

Yang, Z., Schmidt, D., Liu, W., Li, S., Shi, L., Sheng, J., et al. (2014). A novel multivalent, single-domain antibody targeting TcdA and TcdB prevents fulminant Clostridium difficile infection in mice. J. Infect. Dis. 210, 964-972. doi: 10.1093/infdis/jiu196

Yang, Z., Shi, L., Yu, H., Zhang, Y., Chen, K., Saint Fleur, A., et al. (2016). Intravenous adenovirus expressing a multi-specific, single-domain antibody neutralizing TcdA and TcdB protects mice from Clostridium difficile infection. Pathog. Dis. 74:ftw078. doi: 10.1093/femspd/ftw078

Young, K. W., Munro, I. C., Taylor, S. L., Veldkamp, P., and van Dissel, J. T. (2007). The safety of whey protein concentrate derived from the milk of cows immunized against Clostridium difficile. Regul. Toxicol. Pharmacol. 47, 317-326. doi: 10.1016/j.yrtph.2006.12.001

Conflict of Interest Statement: The authors declare that the research was conducted in the absence of any commercial or financial relationships that could be construed as a potential conflict of interest.

Copyright (c) 2018 Förster, Chung, Crobach and Kuijper. This is an open-access article distributed under the terms of the Creative Commons Attribution License (CC $B Y)$. The use, distribution or reproduction in other forums is permitted, provided the original author(s) and the copyright owner are credited and that the original publication in this journal is cited, in accordance with accepted academic practice. No use, distribution or reproduction is permitted which does not comply with these terms. 